\title{
TREATMENT OF IRRITABLE BOWEL SYNDROME: A REVIEW
}

\author{
GUPTA BIKASH* DASH BISWAJIT, PAUL SUJATA, BORA JYOTI ADITYA
}

Department of Pharmaceutics, Girijananda Chowdhury Institute of Pharmaceutical Science Azara, Guwahati - 781 017, Assam, India. Email: bikashgupta1610@gmail.com

Received: 15 March 2018, Revised and Accepted: 02 June 2018

ABSTRACT

Irritable bowel syndrome (IBS) is a gastrointestinal disease which is also called as spastic colon, mucous colitis is characterized by some non-specific symptoms, such as altered bowel habits and abdominal pain, stomach bloating, chronic diarrhea or constipation or alternating between the two. The therapy is based on the healing of symptoms using various pharmaceutical and non-pharmaceutical agents. The objective of treatment is relief from symptom and improved quality of life. The approach for the treatment of IBS is based on the predominant symptoms of the patient. Classical as well as alternative treatment, both appear to be effective for the patients. Classical treatments basically consist of antidiarrheal, antidepressants, antispasmodic, bulking agents, osmotic laxatives, etc. Still, herbal or alternative treatment always seems to be the same beneficiary for the patients due to their negligible adverse effect.

Keywords: Irritable bowel syndrome, Symptoms, Treatment, Alternative treatment, Alter medicine.

(c) 2018 The Authors. Published by Innovare Academic Sciences Pvt Ltd. This is an open access article under the CC BY license (http://creativecommons. org/licenses/by/4. 0/) DOI: http://dx.doi.org/10.22159/ajpcr.2018.v11i9.25953

\section{INTRODUCTION}

Irritable bowel syndrome (IBS) is referred to as a gastrointestinal (GI) syndrome, which is differentiated by altered bowel habits and chronic abdominal pain, and no organic cause is identified for this condition $[1,2]$. IBS is a common disease in the general population and its prevalence varies from country to country and the criteria used for the diagnosis of IBS [3]. It is also described on the basis of symptoms reported by the patients with recurrent abdominal pain or discomfort at least 3 days a month in the previous 3 months, interconnected with two or more of the following: Improvement with defecation, onset associated with a change in frequency of stool, and onset associated with a change in the appearance of stool $[4,5]$. IBS is moreover classified into diarrhea-predominant IBS (IBS-D), constipation-predominant IBS (IBS-C), and mixed symptom IBS (IBS-M) [6,7].

An essential approach expresses that the walls of the digestive organs are fixed with layers of muscle that contract and relax as they move food from one's stomach through the intestinal tract to the rectum. However, people with IBS appear to have an impedance in the communication between the brain, and the musculature of the gut, resulting in too little or a lot of mobility. Besides, triggering of IBS like foods (highly fatty and spicy foods) stress, and beverages (alcohol and caffeine) have a tendency to worsen the symptoms of IBS $[8,9]$.

\section{Pathogenesis}

The underlying causes of IBS remain to be adequately identified.

\section{Serotonin dysregulation}

Serotonin acting, especially through the 5-hydroxytryptamine Type $3\left(5-\mathrm{HT}_{3}\right)$ and $5-\mathrm{H}$ Type $4\left(5-\mathrm{HT}_{4}\right)$ receptors play a critical role in the control of GI motility, sensation, and secretion [10,11]. 5- $\mathrm{HT}_{3}$ receptors are mainly responsible for the regulation of GI motor function through its action on nerve receptors within the enteric nervous system and are involved in the modulation of the visceral sensory function [12]. Moreover, perceptions have demonstrated that plasma 5 -HT concentrations are reduced in IBS patients with constipation but raised in those with diarrhea [13].

\section{The role of bacterial flora in IBS}

Changes in the amount and nature of the microscopic organisms present can pass selective effects on sensory-motor dysfunctions which can be affected by bile acid malabsorption, mucosal irritation and inflammation, increased food fermentation, and gas generation. Increased fecal numbers of lactobacilli, coliform, and bifidobacteria have been reported in patients affected by IBS $[14,15]$. Probiotics have the potential to lessen intestinal permeability and the generation of proinflammatory cytokines that are hoisted in patients with an assortment of hypersensitive disorders [16].

\section{Visceral hypersensitivity}

Visceral hypersensitivity is viewed as a key component in the pathogenesis of pain perception in patients with IBS. Hypersensitivity to swell distension of the rectum was at first identified in $95 \%$ of IBS patients, but subsequently shown to be present in only about half of patients, especially those with IBS-D [17].

\section{TREATMENT}

Medication treatment might be started when IBS symptoms begin to reduce the patient's personal satisfaction. Traditional pharmacological treatment for IBS depends on the event of symptoms. The symptoms are, however, named per the types of IBS.

IBS-C

Fibers

IBS sufferers were recommended to expand dietary fiber supplements. There are mostly two kinds of fiber, that is soluble (e.g. bulking agents - psyllium) and insoluble (e.g. wheat bran). An insoluble fiber causes the gathering of gas, bloating, distension, and abdominal pain. Psyllium hydrophilic mucilloid (ispaghula husk) might be given in a conditional recommendation. A single study reported improvement with calcium polycarbophil. It is one of the helpful treatment for IBS-C treatment which stimulates GI motility and relaxes stool consistency $[18,19]$. Day by day administration of insoluble dietary fiber has a consequent improvement in the severity of constipation. This dietary filament also produced improvements in the patients' motor scoring likely because of better retention of L-dopa, which was clear by substantially higher total plasma L-dopa levels [20]. 


\section{Prokinetics}

Prokinetic is an agent which improves the GI motility by expanding the recurrence of contractions in the small intestine or making them stronger, but without disrupting their rhythm. Examples: VSL\#3, LP299V.

\section{Anticholinergics}

Essentially, it works by decreasing visceral sensation and colonic transit by decreasing the secretion from the intestinal gland. Example: Zamifenacin.

\section{Dopamine antagonists}

Most broadly utilized prokinetic agent was metoclopramide (dopamine antagonist) with central and peripheral effects. Itopride hydrochloride is a prokinetic drug that activates the GI motility through the synergism of its dopamine $\mathrm{D}_{2}$ receptor antagonistic action ant its acetylcholine esterase inhibitory activity [21]. Domperidone, a dopamine antagonist that does not cross the blood-brain barrier and work essentially through peripheral dopamine $\mathrm{A}_{2}$ receptors, is available for use.

\section{Serotonergic agonists}

In the substituted benzamide gathering of prokinetics, cisapride was the prototype [22]. It encourages the release of acetylcholine from myenteric plexus of the neuron through a $5 \mathrm{HT}_{4}$ receptor-mediated effect [23]. In clinical trials, tegaserod ( $5-\mathrm{HT}_{4}$ agonist) has been accounted to diminish the general symptoms of IBS patients in comparison to a tested placebo. Recently, it has been demonstrated that tegaserod may increase the risk of ischemic heart disease when compared to placebo; therefore, the use of this medication was restricted in September 2007. Starting in July 2007 tegaserod was only prescribed to ladies under 55-year-old who suffer from IBS with predominant constipation symptoms and no evident indications of cardiovascular disease [24]. Renzapride (mixed serotonin receptor agonist/antagonist). It might be more effective than a single agent and is prescribed for the therapeutic management of the IBS-C, and it encourages motility [25].

\section{Antibiotics}

There are three general techniques by which the intestinal microflora can be adjusted: Administration of antibiotics or probiotics (i.e. Dietary components that promote the growth and the metabolic activity of beneficial bacteria), or administration of probiotics [26]. Antibiotics are additionally utilized by numerous clinicians to treat IBS symptoms [27]. The enteric flora in IBS patients may differ in correlation with healthy controls which result in increased hydrogen discharge during carbohydrate fermentation. This will further lead to flatulence, constipation and other gastric disturbances. The second line of confirmation to help the utilization of antibiotics in IBS is the connection among IBS and bacterial overgrowth [28,29]. It was recommended to prescribe wide-spectrum antibiotics such as clarithromycin, ciprofloxacin, amoxicillin, metronidazole, rifaximin, and doxycycline for 10 days [30].

\section{Laxatives}

The most critical intestinal medicines are divided into four groups: Fecal softeners (e.g. liquid paraffin), stimulant laxatives (e.g. bisacodyl), osmotic laxatives (e.g. methyl cellulose), and bulk-forming laxatives (ispaghula husk) [31]

\section{Diarrhea predominant IBS}

IBS-D shows quicker intestinal transit when compared with healthy subjects and therefore, agents which delay intestinal transit may be useful in reducing symptoms.

\section{Antispasmodics}

This is the agents which relax smooth muscle by means of calcium channel antagonist, or anticholinergic mechanisms have been ordinarily used for the treatment of IBS. Medication such as alverine, dicyclomine, hyoscyamine, and scopolamine has been used for their effects on GI motility in endeavors to decrease abdominal pain associated with IBS. They are also used in combination with agents such as acetaminophen, simethicone, and benzodiazepines in attempts to enhance GI discomfort [32,33]

\section{Antidiarrheal drugs}

A synthetic phenylpiperidine subsidiary loperamide is first approved by the USFDA for the treatment of diarrhea in 1976. By restraining both intestinal secretion and peristalsis, loperamide slows down intestinal transit and allows for increased fluid reabsorption, hence improving symptoms of diarrhea. Diphenoxylate and atropine in the blend are frequently used to treat symptoms of acute and chronic diarrhea $[34,35]$.

\section{5- $\mathrm{HT}_{3}$ antagonist}

Alosetron is a powerful and specific $5-\mathrm{HT}_{3}$ receptor antagonist. It acts by backing off colonic transit and increase small intestinal fluid absorption and enhances visceral pain [36,37]. For ladies with IBS-D, alosetron has been appearing to be strong in several randomized, placebo-controlled studies [38]. Constipation is the most common adverse effect associated with its utilization [27].

A current meta-investigation and methodical survey of eight randomized controlled trials including 4842 patients verified that alosetron gave a significant reduction in the global symptoms of diarrhea, abdominal pain, and bloating in patients with IBS and diarrhea [31].

\section{Antidepressants}

At a low amount, antidepressant has been appeared to diminish the pain. Tricyclic antidepressants will encourage the arrival of endogenous endorphin and block norepinephrine reuptake, which prompts for the enhancement of descending inhibitory pathway blockage of the pain neuromodulator serotonin. It might moderate intestinal transit time and helps in the treatment of diarrhea. Two late meta-examination assessed randomized control trials of patients taking low-dosage tricyclic antidepressants, such as clomipramine, desipramine, amitriptyline, doxepin, and trimipramine. These examinations demonstrated that tricyclic antidepressants enhance abdominal pain, and diarrhea [39]. Antidepressants are categorized as selective serotonin reuptake inhibitors, tricyclics and related antidepressants, and monoamine oxidase inhibitors. The medication includes duloxetine, flupentixol, mirtazapine, reboxetine, tryptophan, and venlafaxine [40-42].

Newer medicines for both IBS-D and IBS-C

\section{Drugs for diarrhea predominant IBS}

Alosetron

It works by restraining serotonin signals by antagonizing $5-\mathrm{HT}_{3}$ receptors that transmit sensory information (painful and non-painful) from the abdomen to the brain and helps to reduce abdominal pain and diarrhea. It has been affirmed for the use in women with severe IBS-D. It has serious side effects so prescribed under a risk management program requires careful checking and education. Alosetron gave a noteworthy decrease in the worldwide symptoms of diarrhea, abdominal pain, and bloating in patients with IBS and diarrhea. $5-\mathrm{HT}_{3}$ receptors are mostly found in the lumen (enteric nerves) and on higher nerve locations, such as the vomiting center. Obstructing these receptors reduces GI pain, colonic transit, and small intestinal secretion. It is effective in relieving pain and normalizing bowel frequency as well as reducing urgency in diarrhea-predominant, female patients with IBS.

\section{Rifaximin}

It was approved by United States Food and Drug Administration (USFDA) for treatment of IBS-D in adults. It works by bringing down microbes in the gut. A course of 10-14 days has been found to redesign IBS 
Table 1: Conventional pharmacological drugs used for the treatment of IBS [54-56]

\begin{tabular}{|c|c|c|c|c|}
\hline Types of IBS & Treatment types & Sub types & Examples & Structure \\
\hline \multirow[t]{13}{*}{ Constipation predominant IBS } & Fibers & Soluble fibers & Psyllium husk & - \\
\hline & & Insoluble fibers & Wheat bran & - \\
\hline & Prokinetics & Anticholinergic & Zamifenacin & \\
\hline & & Dopamine antagonist & Metoclopramide & \\
\hline & & & Domperidone & \\
\hline & & Serotonergic agonist & Tegaserode & \\
\hline & & & Renzapride (5-HT4 agonist) & \\
\hline & & Antibiotics & Metronidazole & \\
\hline & & & Doxycycline & \\
\hline & Laxatives & Osmotic Laxatives & PEG 3350 & \\
\hline & & Stimulant laxatives & Lactulose & \\
\hline & & Fecal Softeners & Bisacodyl & \\
\hline & & Bulk forming laxatives & Docusate sodium & \\
\hline \multirow[t]{3}{*}{ Diarrhea Predominant IBS } & Antispasmodics & - & Dicyclomine & \\
\hline & Antidiarrheals & - & $\begin{array}{l}\text { Diphenoxylate-atropine combined } \\
\text { Loperamide }\end{array}$ & - \\
\hline & 5-HT3 antagonist & - & Alosetron & \\
\hline
\end{tabular}


Table 1: (Continued)

Types of IBS

IBS: Irritable bowel syndrome

Table 2: Emerging pharmacological drugs used for the treatment of IBS [57-63]

\begin{tabular}{|c|c|c|c|}
\hline Class of drug & Mechanism of action & Examples & Structure \\
\hline$\alpha 2$-adrenergic agonist & Decrease pain sensation and colonic tone & Clonidine & \\
\hline$\kappa$ - opoid agonist & Increase pain thershold induced by distension & Fedotozine, Asimadoline & \\
\hline $\begin{array}{l}\text { Neurokinin } \\
\text { antagonists }\end{array}$ & Decrease visceral sensation & CJ-11974, MEN-11420, nepadutant & --- \\
\hline Somatostatin analogs & $\begin{array}{l}\text { Decrease colonic response to distension } \\
\text { Decrease visceral sensation }\end{array}$ & Octreotide & \\
\hline $\begin{array}{l}\text { Calcium channel } \\
\text { blockers }\end{array}$ & Decrease rectosigmoid response to distension & Verapamil & \\
\hline Oxytocin & $\begin{array}{l}\text { Increase pain threshold induced by colonic } \\
\text { distension }\end{array}$ & & \\
\hline Neutrophils & Improve constipation & Recombinant human neutrophin-3 & - \\
\hline Probiotics & Improve balance of intestinal flora & VSL\#3, LP299V & - \\
\hline
\end{tabular}

IBS: Irritable bowel syndrome

symptoms of bloating and diarrhea. Although few patients experience relief of IBS symptoms after taking a course of rifaximin, others require treatment (up to 2 times at the same dosage). It is slightly absorbed in the gut and is generally tolerated well. An underlying little randomized, controlled trial by Pimentel et al. in 87 patients with IBS suggested that a 10 days course of rifaximin $400 \mathrm{mg} 3$ times daily improved patient global scores of symptoms compared to placebo $[29,43]$.

\section{Eluxadoline}

In May 2015, USFDA has approved this medication. It is prescribed for the treatment of IBS-D in adult, men, and women. It likewise diminishes abdominal pain and improves stool consistency. It controls GI motility, secretions, and visceral sensations. It is a mixed mu opioid receptor agonist with a delta-opioid receptor antagonist activity and kappa-opioid agonist activity. An estimated 95\% of patients with IBS experience enhanced visceral and sensory responses, which contribute to the symptoms of pain, gas, and intestinal contractions [44].
In patients with IBS-D, there is expanded colonic transit and enhanced peristaltic contractions, most notably after meals. A mixed-opioid medication, such as eluxadoline, provides relief of IBS-D related symptoms with lower rates of side effects, specifically constipation. Pain medications that solely target the mu opioid receptor are known to cause noteworthy constipation and potential for tolerance or dependence. Eluxadoline targets local opioid receptors in the gut, which decreases the chance of additional central nervous system side effects $[45,46]$.

\section{Drugs for IBS-C}

\section{Lubiprostone}

This medication has been appearing to be viable for treating constipation symptoms. It promotes secretion through chloride channels in the digestive tract, which, in turn, stimulate peristalsis, the coordinated muscle contractions that propel the substance through the GI tract. It was FDA approved in 2006 for the treatment of chronic idiopathic 
Table 3: Herbal drugs used for the treatment of IBS

\begin{tabular}{|c|c|c|c|c|}
\hline Drug & Biological source & $\begin{array}{l}\text { Active } \\
\text { constituent }\end{array}$ & Structure & Mode of action \\
\hline Peppermint oil & $\begin{array}{l}\text { Mentha×piperita (leaves) } \\
\text { Family: Lamiaceae }\end{array}$ & Menthol & & $\begin{array}{l}\text { Calcium channel blocker, Spasmolytic activity on GI } \\
\text { smooth muscle }\end{array}$ \\
\hline Turmeric extract & $\begin{array}{l}\text { Curcuma } \\
\text { longa (rhizomes) } \\
\text { Family: Zingiberaceae }\end{array}$ & Curcumin & & $\begin{array}{l}\text { Calcium channel blocker in hyperactive state, } \\
\text { Spasmolytic activity on GI smooth muscle }\end{array}$ \\
\hline Ginger oil & $\begin{array}{l}\text { Zingiber officinalis } \\
\text { (rhizomes) } \\
\text { Family: Zingiberaceae }\end{array}$ & Gingerol & & Carminative, anti-flatulence and Anti-inflammatory \\
\hline
\end{tabular}

IBS: Irritable bowel syndrome

constipation at a dose of $24 \mu \mathrm{g}$ taken twice per day. This approval was based on the results of two 12 weeks randomized phase trials that were published in one manuscript in 2009. It is approved for use in women with IBS-C, and in men and women with chronic constipation (without predominant abdominal pain) [47]

\section{Linaclotide}

It is 14-amino acid synthetic peptide guanylate cyclase-C agonists. It works by increasing the movement of a substance through the GI tract and by blocking pain signals in the intestines. Activation of guanylate cyclase receptors leads to increased secretion of both guanylin and uroguanylin into the intestinal lumen where they act as a second messenger for both electrolyte and fluid release into the large bowel [48-50].

The medicine is prescribed for the treatment of IBS with constipation and chronic idiopathic constipation. I consider, patients taking linaclotide experienced improvement in multiple symptoms, including pain or discomfort, bloating, and bowel function. Preliminary clinical studies were conducted in the mid-2000s and found the medication to have significant effects on ascending colonic transit time and clinical symptoms related to stooling. Diarrhea, abdominal pain, flatulence, and abdominal distension are the most common adverse effects of this drug [51-53].

\section{TREATMENT OF MIXED SYMPTOM IBS}

The symptoms for mixed symptom IBS involve an alternating cycle of diarrhea and constipation. Treatment of alternating type IBS or what we called as mixed symptom IBS can be challenging. Henceforth, treatment regimen is classified into a combination of both IBS-D and IBS-C. This is because of the fact that bowel symptoms move to and fro from diarrhea to constipation and back again. It is a common concern that steps taken to address one symptom will result in bringing on the unwanted effects of the other. However, we can take a portion of the measures to keep up the side effects.

\section{Alternative treatment of IBS}

\section{Peppermint oil}

Peppermint oil is extracted from Mentha piperita, Lamiaceae by the steam distillation process are among the oldest remedies for the treatment of GI issues. The major constituent of peppermint oil is menthol, which has an antispasmodic agent that blocks L-type calcium channels, resulting in GI smooth muscle relaxation [64-66]. It applies a spasmolytic effect on the smooth muscles in the digestive tract and believed to improve IBS symptoms. Gastroesophageal reflux is the most common adverse effect associated with oral peppermint oil. Peppermint oil is a standout among the most commonly used over-thecounter remedies [67-69].

\section{Turmeric extract}

It is obtained from the dried rhizome of Curcuma longa, Zingiberaceae. The extract of rhizomes tends to show maximum activity for the symptoms of IBS. 8-week treatment of IBS patients with C. longa extract tablet tends to decrease IBS prevalence and abdominal pain/ discomfort [70]. The inhibitory effects of the extract of turmeric (curcumin) are mediated fundamentally through a calcium channel blockade in hyperactive states of the gut and airways [71].

\section{Ginger rhizomes}

It is the oleoresin obtained from the fresh rhizome of Zingiber officinale, Zingiberaceae. Ginger dosing is standardized according to gingerol content which is accepted to have antiemetic, pain relieving, sedative, antibacterial, and other physiological effects [72]. It has an aromatic odor and tangy and pungent taste [73].

\section{Chamomile drops}

It consists of dried flowering tops of chamomile Matricaria chamomilla, Asteraceae. The flowers of chamomile contain 1-2\% volatile oils including alpha-bisabolol, alpha-bisabolol oxides A and B, and matricin (usually converted to chamazulene and other flavonoids. Which possess anti-inflammatory and antiphlogistic properties) [74-76].

Chamomile is especially helpful in eliminating gas, soothing the stomach, and relaxing the muscles that move food through the intestines. Chamomile is used traditionally for digestive disorders, "spasm" or colic, upset stomach, flatulence (gas), ulcers, and GI irritation as well as disorders of the nervous system and dysmenorrhea $[77,78]$.

\section{CONCLUSION}

The IBS is the most common GI disorder seen in primary care. The pathophysiology of the IBS is complex and unclear. Both central and 
peripheral factors, including psychosocial factors, abnormal GI motility and secretion, and visceral hypersensitivity, are thought to contribute to the symptoms of the IBS. The main focus of this review article has been on the treatment of IBS such as IBS-C, IBS-D, and mixed symptom IBS using some of the current and emerging drugs. However, therapies are being developed that target some of the important pathophysiological mechanisms.

\section{ACKNOWLEDGMENTS}

The authors thankful to Principal, Dr. Gauranga Das of Girijananda Chowdhury Institute of Pharmaceutical Science Azara, Guwahati, India, for providing his support and facility to complete this review work.

\section{AUTHOR'S CONTRIBUTIONS}

All the authors were equally involved in the drafting, assembling information, and design of the manuscript.

\section{CONFLICTS OF INTEREST}

There are no conflicts of interest.

\section{REFERENCES}

1. Sameer A, Faisal A, Abdullah A, Ahmad B, Abdulaziz A, Abdulrahman A, et al. A study of impact and prevalence of irritable bowel syndrome among medical students. Int J Med Med Sci 2015;7:139-47.

2. Chey WD, Kurlander ES. Irritable bowel syndrome: A clinical review. JAMA 2015;313:949-58.

3. Quigley EM, Abdel HH, Barbara GB, Boeckxstaens SJ, Giorgio G, Delvaux R, et al. A global perspective on irritable bowel syndrome: A consensus statement of the world gastroenterology organization summit task force on irritable bowel syndrome. J Clin Gastroenterol 2001;46:356-66

4. Chang L, Lembo A, Sultan S. American gastroenterological association institute technical review on the pharmacological management of irritable bowel syndrome. Gastroenterology 2014;147:1149-7200.

5. Lovell RM, Ford AC. Global prevalence of and risk factors for irritable bowel syndrome: A meta-analysis. Clin Gastroenterol Hepatol 2012;10:712-210000.

6. Chang FY, Chen CL. The current prevalence of irritable bowel syndrome in Asia. J Neurogastroenterol Motil 2010;16:389-400.

7. Longstreth GF, Thompson WG, Chey WD, Houghton LA, Mearin F, Spiller RC, et al. Functional bowel disorders. Gastroenterology 2006;130:1480-91.

8. Horwitz BJ, Fisher RS. The irritable bowel syndrome. World J Gastroenterol 2014;20:12144-60.

9. Makharia GK, Verma AK, Amarchand R, Goswami A, Singh P, Agnihotri A, et al. Prevalence of irritable bowel syndrome: A community based study from northern India. J Neurogastroenterol Motil 2011;17:82-7.

10. Barbara G, Dolci M, Cremon C, Barbora MR, Bellacosa L, Fucili A, et al. Understanding the pathophysiology of IBS. Eur Med J Gastroenterol 2013;1:40-6.

11. Crowell MD. The role of serotonin in the pathophysiology of irritable bowel syndrome. Am J Manag Care 2001;7:S252-60.

12. Jose S, Dhanya K, Cinu TA, Aleykutty NA. Multiparticulate system for colon targeted delivery of ondansetron. Indian $\mathrm{J}$ Pharm Sci 2010;72:58-64.

13. De Ponti F. Pharmacology of serotonin: What a clinician should know. Gut 2004:53:1520-35

14. Kassinen A, Krogius-Kurikka L, Mäkivuokko H, Rinttilä T, Paulin L, Corander J, et al. The fecal microbiota of irritable bowel syndrome patients differs significantly from that of healthy subjects. Gastroenterology 2007;133:24-33.

15. Spiller R. Review article: Probiotics and prebiotics in irritable bowel syndrome. Aliment Pharmacol Ther 2008;28:385-96.

16. Christina W, Susan P. Prebiotics and Probiotics for Prevention of Allergic Disease. Waltham: UpToDate; 2011.

17. Derbyshire SW. A systematic review of neuroimaging data during visceral stimulation. Am J Gastroenterol 2003;98:12-20.

18. Bijkerk CJ, Muris JW, Knottnerus JA, Hoes AW, de Wit NJ. Systematic review: The role of different types of fibre in the treatment of irritable bowel syndrome. Aliment Pharmacol Ther 2004;19:245-51.
19. Ford AC, Talley NJ, Spiegel BM, Foxx-Orenstein AE, Schiller L, Quigley EM, et al. Effect of fibre, antispasmodics, and peppermint oil in the treatment of irritable bowel syndrome: Systematic review and meta-analysis. BMJ 2008;337:a2313.

20. Johnson ME, Johnson JL. Management of slow colonic transit constipation in Parkinson's disease: Current evidence and a community pharmacy perspective. Int J Pharm Pharm Sci 2016;8:28-34

21. Chandira RM, Bhowmik D, Jayakar CB. Formulation and evaluation of gastroretentive drug delivery system of gastroprokinetic drug itopride hydrochloride. Int J Pharm Pharm Sci 2010;2:53-65.

22. Spiller R. Serotonergic modulating drugs for functional gastrointestinal diseases. Br J Clin Pharmacol 2002;54:11-20.

23. Grider JR, Foxx-Orenstein AE, Jin JG 5-hydroxytryptamine4 receptor agonists initiate the peristaltic reflex in human, rat, and guinea pig intestine. Gastroenterology 1998;115:370-80.

24. Prather CM, Camilleri M, Zinsmeister AR, McKinzie S, Thomforde G. Tegaserod accelerates orocecal transit in patients with constipationpredominant irritable bowel syndrome. Gastroenterology 2000;118:463-8.

25. Khoshoo V, Armstead C, Landry L. Effect of a laxative with and without tegaserod in adolescents with constipation predominant irritable bowel syndrome. Aliment Pharmacol Ther 2006;23:191-6.

26. Cherian S, Anitha S. Study of the prescribing pattern of probiotics in paediatric patients of a tertiary care teaching hospital, South India. Int J Pharm Pharm Sci 2012;4:505-8.

27. Lembo T, Wright RA, Bagby B, Decker C, Gordon S, Jhingran P, et al. Alosetron controls bowel urgency and provides global symptom improvement in women with diarrhea-predominant irritable bowel syndrome. Am J Gastroenterol 2001;96:2662-70.

28. Das RR, Singh M, Nusrat S. Probiotics for prevention or treatment of asthma. Pediatr Asthma Posters 2017

29. Salman FZ, Ferreira NL, Enoch B, Tina WU, Kecia C, William PF, et al. T1411 Predictors of clinical response from a phase 2 multi center efficacy trial using rifaximin, a gut-selective, nonabsorbed antibiotic for the treatment of diarrhea-associated Irritable bowel syndrome. Gastroenterology 2008;134:545-50

30. Lembo A, Zakko SF, Ferreira NL. Rifaximin for the treatment of diarrhea associated irritable bowel syndrome: Short term treatment leading to long term sustained response. Clin Exp Gastroenterol 2012;5:69-100

31. Pimentel M, Park S, Mirocha J, Kane SV, Kong Y. The effect of a nonabsorbed oral antibiotic (rifaximin) on the symptoms of the irritable bowel syndrome: A randomized trial. Ann Intern Med 2006;145:557-63.

32. Coleman N, Spiller R. New pharmaceutical approaches to the treatment of IBS: Future development and research. Ann Gasteroenterol 2002;15:278-89.

33. Mueller-Lissner S, Tytgat GN, Paulo LG, Quigley EM, Bubeck J, Peil $\mathrm{H}$, et al. Placebo- and paracetamol-controlled study on the efficacy and tolerability of hyoscine butylbromide in the treatment of patients with recurrent crampy abdominal pain. Aliment Pharmacol Ther 2006;23:1741-8.

34. Ritchie JA, Truelove SC. Treatment of irritable bowel syndrome with lorazepam, hyoscine butylbromide, and ispaghula husk. Br Med J 1979; $1: 376-8$

35. Lacy BE, Kirsten W, Lee RD. The treatment of irritable bowel syndrome. Ther Adv Gastroenterol 2009;2:221-38.

36. Mayer EA, Berman S, Derbyshire SW, Suyenobu B, Chang L, Fitzgerald L, et al. The effect of the 5-HT3 receptor antagonist, alosetron, on brain responses to visceral stimulation in irritable bowel syndrome patients. Aliment Pharmacol Ther 2002;16:1357-66.

37. Camilleri M, Chey WY, Mayer EA, Northcutt AR, Heath A, Dukes GE, et al. A randomized controlled clinical trial of the serotonin type 3 receptor antagonist alosetron in women with diarrhea-predominant irritable bowel syndrome. Arch Intern Med 2001;161:1733-40.

38. Camilleri M, Kerstens R, Rykx A, Vandeplassche L. A placebocontrolled trial of prucalopride for severe chronic constipation. N Engl J Med 2008;358:2344-54.

39. Rivkin A, Rybalov S. Update on the management of diarrheapredominant irritable bowel syndrome: Focus on rifaximin and eluxadoline. Pharmacotherapy 2016;36:300-16.

40. Clouse RE, Lustman PJ. Use of psychopharmacological agents for functional gastrointestinal disorders. Gut 2005;54:1332-41.

41. Drossman DA, Morris CB, Schneck S, Hu YJ, Norton NJ, Norton WF, et al. International survey of patients with IBS: Symptom features and their severity, health status, treatments, and risk taking to achieve clinical benefit. J Clin Gastroenterol 2009;43:541-50

42. Drossman DA. Beyond tricyclics: New ideas for treating patients with 
painful and refractory functional gastrointestinal symptoms. Am J Gastroenterol 2009;104:2897-902.

43. Pimentel M, Lembo A, Chey WD, Zakko S, Ringel Y, Yu J, et al. Rifaximin therapy for patients with irritable bowel syndrome without constipation. N Engl J Med 2011;364:22-32.

44. Lembo AJ, Brian E, Lacy MJ, Schey R, Dove LS, David AA, et al. Eluxadoline for irritable bowel syndrome with diarrhea. N Engl J Med 2016;374:242-53.

45. Davenport JM, Covington P, Bonifacio L, McIntyre G, Venitz J. Effect of uptake transporters OAT3 and OATP1B1 and efflux transporter MRP2 on the pharmacokinetics of eluxadoline. J Clin Pharmacol 2015;55:534-42.

46. Drossman DA, Chey WD, Johanson JF, Fass R, Scott C, Panas R, et al. Clinical trial: Lubiprostone in patients with constipation-associated irritable bowel syndrome - results of two randomized, placebocontrolled studies. Aliment Pharmacol Ther 2009;29:329-41.

47. Bryant AP, Busby RW, Bartolini WP, Cordero EA, Hannig G, Kessler MM, et al. Linaclotide is a potent and selective guanylate cyclase $\mathrm{C}$ agonist that elicits pharmacological effects locally in the gastrointestinal tract. Life Sci 2010;86:760-5.

48. Andresen V, Camilleri M, Busciglio IA, Grudell A, Burton D, McKinzie S, et al. Effect of 5 days linaclotide on transit and bowel function in females with constipation-predominant irritable bowel syndrome. Gastroenterology 2007;133:761-8.

49. Lacy BE, Levy LC. Lubiprostone: A novel treatment for chronic constipation. Clin Interv Aging 2008;3:357-64.

50. Barish CF, Drossman D, Johanson JF, Ueno R. Efficacy and safety of lubiprostone in patients with chronic constipation. Dig Dis Sci 2010;55:1090-7.

51. Johnston JM, Kurtz CB, Macdougall JE, Lavins BJ, Currie MG, Fitch DA, et al. Linaclotide improves abdominal pain and bowel habits in a phase IIb study of patients with irritable bowel syndrome with constipation. Gastroenterology 2010;139:1877-8600.

52. American College of Gastroenterology Task Force on Irritable Bowel Syndrome, Brandt LJ, Chey WD, Foxx-Orenstein AE, Schiller LR, Schoenfeld PS, et al. An evidence-based position statement on the management of irritable bowel syndrome. Am J Gastroenterol 2009;104 Suppl 1:S1-35

53. Chey WD, Lembo AJ, Lavins BJ, Shiff SJ, Kurtz CB, Currie MG, et al. Linaclotide for irritable bowel syndrome with constipation: A 26-week, randomized, double-blind, placebo-controlled trial to evaluate efficacy and safety. Am J Gastroenterol 2012;107:1702-12.

54. Drossman DA, Camilleri M, Mayer EA, Whitehead WE. AGA technical review on irritable bowel syndrome. Gastroenterology 2002; $123: 2108-31$

55. Somers SC, Lembo A. Irritable bowel syndrome: Evaluation and treatment. Gastroenterol Clin North Am 2003;32:507-29.

56. Brandt LJ, Bjorkman D, Fennerty MB, Locke GR, Olden K, Peterson W, et al. Systematic review on the management of irritable bowel syndrome in North America. Am J Gastroenterol 2002;97:S7-26.

57. Lembo T, Rink R. Current pharmacologic treatments of irritable bowel syndrome. participate (international foundation for functional gastrointestinal disorders). N Engl J Med 2002;11:1-4.

58. Berrada D, Canenguez K, Lembo T. New approaches to the medical treatment of irritable bowel syndrome. Curr Gastroenterol Rep $2003 ; 5: 337-42$.
59. Camilleri M. Review article: Clinical evidence to support current therapies of irritable bowel syndrome. Aliment Pharmacol Ther 1999; 13 Suppl 2:48-53.

60. Ahn J, Ehrenpreis ED. Emerging treatments for irritable bowel syndrome. Expert Opin Pharmacother 2002;3:9-21.

61. Camilleri M. Novel pharmacology: Asimadoline, a kappa-opioid agonist, and visceral sensation. Neurogastroenterol Motil 2008;20:971-9.

62. Shekhar C, Whorwell PJ. Emerging drugs for irritable bowel syndrome. Expert Opin Emerg Drugs 2009;14:673-85

63. Delgado-Aros S, Chial HJ, Cremonini F, Ferber I, McKinzie S, Burton DD, et al. Effects of asimadoline, a kappa-opioid agonist, on satiation and postprandial symptoms in health. Aliment Pharmacol Ther 2003;18:507-14.

64. Grigoleit HG, Grigoleit P. Pharmacology and preclinical pharmacokinetics of peppermint oil. Phytomedicine 2005;12:612-6.

65. Hawthorn M, Ferrante J, Luchowski E, Rutledge A, Wei XY, Triggle DJ, et al. The actions of peppermint oil and menthol on calcium channel dependent processes in intestinal, neuronal and cardiac preparations. Aliment Pharmacol Ther 1988;2:101-18.

66. Amato A, Liotta R, Mulè F. Effects of menthol on circular smooth muscle of human colon: Analysis of the mechanism of action. Eur $\mathrm{J}$ Pharmacol 2014;740:295-301.

67. Liu JH, Chen GH, Yeh HZ, Huang CK, Poon SK. Enteric-coated peppermint-oil capsules in the treatment of irritable bowel syndrome: A prospective, randomized trial. J Gastroenterol 1997;32:765-8.

68. Pittler MH, Ernst E. Peppermint oil for irritable bowel syndrome: A critical review and metaanalysis. Am J Gastroenterol 1998;93:1131-5.

69. Hills JM, Aaronson PI. The mechanism of action of peppermint oil on gastrointestinal smooth muscle. An analysis using patch clamp electrophysiology and isolated tissue pharmacology in rabbit and guinea pig. Gastroenterology 1991;101:55-65.

70. Gilani AH, Shah AJ, Ghayur MN, Majeed K. Pharmacological basis for the use of turmeric in gastrointestinal and respiratory disorders. Life Sci 2005;76:3089-105

71. Ghayur MN, Gilani AH. Pharmacological basis for the medicinal use of ginger in gastrointestinal disorders. Dig Dis Sci 2005;50:1889-97.

72. Lemberkovics E, Kéry A, Marczal G, Simándi B, Szöke E. Phytochemical evaluation of essential oils, medicinal plants and their preparations. Acta Pharm Hung 1998;68:141-9.

73. Kala C, Ali SS, Chaudhary S. Comparative pharmacognostical evaluation af Costus speciosus (Wild Ginger) and Zingiber officinale (Ginger) rhizome. Int J Curr Pharm Res 2016;8:19-23.

74. Carnat A, Carnat AP, Fraisse D, Ricoux L, Lamaison JL. The aromatic and polyphenolic composition of roman camomile tea. Fitoterapia 2004;75:32-8.

75. Sakai H, Misawa M. Effect of sodium azulene sulfonate on capsaicininduced pharyngitis in rats. Basic Clin Pharmacol Toxicol 2005;96:54-9.

76. Pena D, Montes de Oca N, Rojas S. Anti-inflammatory and antidiarrheic activity of Isocarpha cubana Blake. Pharmacologyonline 2006;3:744-9.

77. Kroll U, Cordes C. Pharmaceutical prerequisites for a multi-target theray. Phytomedicine 2006;5:12-9.

78. Akram M, Siddiqui MI, Akhter N, Waqas MK, Iqbal Z, Khan AA, et al. Herbal treatment of irritable bowel syndrome: A review. J Med Plants Res 2011;5:6934-8. 